\title{
Awareness of consequences of obesity on reproductive health problems among women in an urban area in South India
}

\author{
Nitin Joseph $^{1 *}$, Sneha V.2, Maria Nelliyanil ${ }^{3}$, Sharada Rai ${ }^{2}$, Supriya K. ${ }^{4}$, Kamalakshi Bhat ${ }^{5}$
}

\author{
${ }^{1}$ Department of Community Medicine, ${ }^{2} \mathrm{MBBS}$ student, ${ }^{4}$ Department of Obstetrics and Gynaecology, ${ }^{5}$ Department of \\ Paediatrics, Kasturba Medical College, Light House Hill Road, Manipal University, Mangalore, India \\ ${ }^{3}$ Department of Community Medicine, A.J Institute of Medical Sciences, Mangalore, India
}

Received: 01 June 2015

Accepted: 30 June 2015

\author{
*Correspondence: \\ Dr. Nitin Joseph, \\ E-mail: drnitinjoseph@gmail.com
}

Copyright: (c) the author(s), publisher and licensee Medip Academy. This is an open-access article distributed under the terms of the Creative Commons Attribution Non-Commercial License, which permits unrestricted non-commercial use, distribution, and reproduction in any medium, provided the original work is properly cited.

\begin{abstract}
Background: Obesity is a well-known risk factor for number of non-communicable diseases. There is paucity of data however with regard to awareness of its consequences on reproductive health hazards.

Methods: Data was collected from 208 women aged $\geq 18$ years from households chosen by systematic random sampling in an urban area.

Results: The mean age of participants was $41.4 \pm 14.2$ years. Majority of them completed their graduation $[109(52.4 \%)]$ and were housewives [80(38.5\%)]. Most of them were married [167(80.3\%)]. Out of 208 study participants, 166(79.8\%) knew that obesity adversely affects reproductive health causing problems like PIH [156(75.0\%)], GDM [150(72.1\%)], menstrual irregularities [130(62.5\%)], infertility [117(56.2\%)], decreased efficacy of hormonal contraception [84(40.4\%)], premature delivery [67(32.2\%)], miscarriages [66(31.7\%)] and fetal malformations [55(26.4\%)] during pregnancy. Difficulties during delivery [137(65.9\%)], higher chances of caesarean section $[130(62.4 \%)]$, infections [36(17.3\%)] and PPH [33(15.9\%)] in the intra and post natal period were also known to participants. Majority of women [158(76\%)] had average awareness level regarding consequences of obesity on their reproductive health. Only $21(10.1 \%)$ had good awareness. Source of information among majority of participants was media [116(55.8\%)]. Good awareness level was significantly more among those aged $\leq 25$ years $(p=0.03)$, with higher level of education $(\mathrm{p}=0.038)$, nulligravida $(\mathrm{p}=0.037)$ and professionals $(\mathrm{p}=0.02)$.

Conclusions: Awareness generation on consequences of obesity on reproductive health is required to bring about behavioral change regarding obesity prevention among women in the setting.
\end{abstract}

Keywords: Awareness, Reproductive health problems, Obesity, Women, Urban area

\section{INTRODUCTION}

Obesity is a growing problem among women in reproductive age group in India. As per the recent National family health survey (NFHS-3), $12.6 \%$ women were either overweight or obese. This was almost $25 \%$ more than the previous NFHS-2 survey. The situation is far more serious in urban parts of India where $23.5 \%$ women are currently either overweight or obese. ${ }^{1}$
Obesity is a well-known risk factor for a number of noncommunicable diseases in the long run. But for women in the reproductive age group the immediate concern should be its effects on poor reproductive outcomes. Studies have found that in the antenatal period, obesity causes increased risks of infertility ${ }^{2,3}$, miscarriage ${ }^{4,5}$, pre-term birth $^{6}$, preeclampsia ${ }^{7,8}$ and gestational diabetes mellitus (GDM). ${ }^{9}$ Increased risk of cesarean sections ${ }^{10,11}$, prolonged labour ${ }^{12}$ and postpartum anemia ${ }^{13}$ are complications caused by obesity in intra and post natal 
period. Apart from these complications are the technical problems associated with managing obese pregnant mothers during antenatal care as a consequence of reduced ultrasound accuracy, requirement of larger cuff to measure blood pressure and difficulty posed during external electronic foetal monitoring. ${ }^{14}$

Prior studies have also found neonatal complications such as stillbirths ${ }^{15,16}$, congenital anomalies ${ }^{17,18}$ and macrosomia $^{6}$ as well as gynecological problems like risk of breast cancer ${ }^{19}$ and endometrial cancer ${ }^{20}$ to be due to obesity.

Though several studies have assessed the awareness of people about role of obesity in cardio-metabolic diseases, very few studies have assessed awareness of its consequences on women's reproductive health. The current obesity epidemic reflects the deep rooted influence of cultural practices in the society which prevents behavioral change among people in the developing world. $^{21,22}$ But health education by enlightening women on prevention of obesity for successful outcome of pregnancies would probably bring about behavioral modifications. ${ }^{15}$ As a consequence of this the reproductive health outcomes will improve in this setting. This study was hence done to assess the level of awareness of consequences of obesity on reproductive health and to find out its association with socio demographic variables among women in a coastal city of south India.

\section{METHODS}

This cross sectional study was conducted from February to April 2014 in two randomly chosen wards in Mangalore. The ethical approval for conducting this study was obtained from the institutional ethics committee. The sample size of 185 participants was calculated at $95 \%$ confidence limits, $80 \%$ power and based on the awareness of consequences of obesity among women found to be $35 \%$ from a previously done study. ${ }^{15}$ Adding a non-response rate of $10 \%$, the total sample size was calculated as 208. These participants were chosen from households by systematic random sampling. Here every 10th house starting from the first house chosen by simple random sampling technique was surveyed. In case the house was locked or members were ineligible for inclusion in this study or were non consenting the next adjacent house was selected. Any woman aged $\geq 18$ years, literate and consenting to participate per house was enrolled in this study. Written informed consent was obtained from each participant after explaining to them the nature and purpose of the study using an information sheet printed in local language Kannada. The data was collected using a selfadministered questionnaire printed in Kannada.

The reliability of the questionnaire was determined in a pilot study among 10 non randomly chosen participants who were not part of the main study. The Cronbachs alpha value of internal consistency of the questionnaire was found to be 0.84 .

It contained questions related to socio-demographic details of participants, awareness regarding consequences of obesity on menstrual cycle, fertility, antenatal period, intrapartum period, postpartum period, fetus and other aspects like cancers of female genital tract.

This questionnaire was developed by investigators based on current literature on the consequences of obesity on reproductive outcomes. Content validation of questionnaire was done by experts from the Departments of Obstetrics and Gynecology and Pediatrics. Language validation of the questionnaire was done by translating it into Kannada and then back translating it into English by two different language experts.

There were a total of 23 questions to assess the awareness of study participants regarding consequences of obesity on reproductive health. For every correct response one mark was awarded and zero marks were given if response was wrong or when participants were not sure about the answer. Awareness level of participants was categorized as poor, average and good if the cumulative score was in the range 0 to 4,5 to 15 and 16 to 23 respectively. These categories were defined based on the total possible scores for "must know" and "nice-to-know" questions. The cutoff value for points below which performance was labelled as poor was based on the cumulative points allocated to "must know" questions in the questionnaire. Similarly the lower limit for good performance was based on the cumulative points for "nice to know" questions made less from the maximum score of 23. The must know questions were questions related to awareness of study participants regarding role of obesity in conditions like GDM, pregnancy induced hypertension (PIH) and difficulties during delivery.

The awareness of study participants regarding consequences of obesity on obstetric health was categorized into poor ( 0 to 3 ), average (4 to 13) and good (14 to 17). Similarly awareness of study participants regarding consequences of obesity on gynecological health was also categorized into poor ( 0 or 1$)$, average (2) and good (3 to 6) based on scores.

Each participant was provided a pamphlet containing answers to various questions listed in the questionnaire printed in Kannada after they handed over the filled in questionnaire to the investigators.

Data was entered and analyzed using Statistical Package for Social Sciences software (SPSS Inc., Chicago, IL) version 11. Chi-square and One way Analysis of Variance was used to test association of various socio demographic variables with level of awareness among participants. $\mathrm{p}$ value less than 0.05 was taken as statistically significant association. 


\section{RESULTS}

The mean age of the total 208 participants was $41.4 \pm 14.2$ years. Majority of them completed their graduation [109(52.4\%)], were housewives [80(38.5\%)] and were married [167(80.3\%)]. Most of the participants $[152(73.1 \%)]$ were pregnant at least once in the past. Majority of the participants $[166(79.8 \%)]$ knew that obesity adversely affects reproductive health causing problems like PIH [156(75.0\%)], GDM [150(72.1\%)], difficulties during delivery [137(65.9\%)], higher chances of caesarean section [130(62.5\%)], menstrual irregularities [130(62.5\%)], infertility [117(56.2\%)], decreased efficacy of hormonal contraception $[84(40.4 \%)]$, premature delivery [67(32.2\%)], miscarriages $[66(31.7 \%)]$ and foetal malformations [55(26.4\%)] during pregnancy.
Majority of them were not sure if obesity causes genital cancers [114(54.8\%)], stillbirth [113(54.3\%)], increased chances of impaired outcome of assisted reproductive techniques [92(44.2\%)], foetal malformations [92(44.2\%)], polycystic ovarian disease [82(39.4\%)], difficulties in appreciating foetal heart sounds using stethoscope [79(38.0\%)], difficulties in performing ultrasound examination of abdomen [78(37.5\%)], premature delivery $[75(36.1 \%)]$ and miscarriage [74(35.6\%)]. Most of them thought that obesity does not cause difficulties in measuring blood pressure using sphygmomanometer [99(47.6\%)], increase in the cost of antenatal care $[99(47.6 \%)]$ and delivery of big baby [96(46.2\%)]. Most participants [202(97.1\%)] felt that more awareness programs should be conducted to provide more information regarding consequences of obesity on reproductive health among women (Table 1).

Table 1: Awareness regarding health hazards of obesity on reproductive health of women among study participants $(n=208)$.

\begin{tabular}{|c|c|c|c|}
\hline Questions & Yes $(\%)$ & No $(\%)$ & $\begin{array}{l}\text { Don't } \\
\text { know }(\%)\end{array}$ \\
\hline $\begin{array}{l}\text { Do you think obesity adversely affects reproductive health of } \\
\text { women? }\end{array}$ & $166(79.8)$ & $29(13.9)$ & $13(6.2)$ \\
\hline Do you think obesity could cause menstrual irregularities? & $130(62.5)$ & $37(17.8)$ & $41(19.7)$ \\
\hline Is obesity one of the causes for infertility? & $117(56.2)$ & $37(17.8)$ & $54(26)$ \\
\hline $\begin{array}{l}\text { Do you think obesity could decrease the efficacy of hormonal } \\
\text { contraceptives? }\end{array}$ & $84(40.4)$ & $45(21.6)$ & $79(38)$ \\
\hline $\begin{array}{l}\text { Do you think obesity could impair outcome of assisted } \\
\text { reproductive technologies? }\end{array}$ & $76(36.5)$ & $40(19.2)$ & $92(44.2)$ \\
\hline $\begin{array}{l}\text { Does obesity in pregnant lady increase the chances of } \\
\text { miscarriage? }\end{array}$ & $66(31.7)$ & $68(32.7)$ & $74(35.6)$ \\
\hline Do you think obesity during pregnancy result in healthier baby? & $16(7.7)$ & $159(76.4)$ & $33(15.9)$ \\
\hline $\begin{array}{l}\text { Does obesity in pregnancy increase risk of foetal } \\
\text { malformations? }\end{array}$ & $55(26.4)$ & $61(29.3)$ & $92(44.2)$ \\
\hline Does obesity increase chance of premature delivery? & $67(32.2)$ & $66(31.7)$ & $75(36.1)$ \\
\hline $\begin{array}{l}\text { Do you think obese women have more chances of developing } \\
\text { diabetes mellitus during pregnancy? }\end{array}$ & $150(72.1)$ & $21(10.1)$ & $37(17.8)$ \\
\hline $\begin{array}{l}\text { Do you think obesity could increase the risk of developing } \\
\text { hypertension during pregnancy? }\end{array}$ & $156(75)$ & $24(11.5)$ & $28(13.5)$ \\
\hline $\begin{array}{l}\text { Does obesity cause difficulties in performing ultrasound } \\
\text { examination of abdomen? }\end{array}$ & $54(26)$ & $76(36.5)$ & $78(37.5)$ \\
\hline $\begin{array}{l}\text { Does obesity cause difficulties in measuring heart sounds of } \\
\text { foetus in abdomen using a stethoscope? }\end{array}$ & $66(31.7)$ & $63(30.3)$ & $79(38)$ \\
\hline $\begin{array}{l}\text { Do you think obesity would cause difficulties in measuring } \\
\text { blood pressure accurately with sphygmomanometer? }\end{array}$ & $61(29.3)$ & $99(47.6)$ & $48(23.1)$ \\
\hline $\begin{array}{l}\text { Do you think obese women might have difficulties during } \\
\text { delivery? }\end{array}$ & $137(65.9)$ & $37(17.8)$ & $34(16.3)$ \\
\hline $\begin{array}{l}\text { Do you think obesity could increase the risk of caesarean section } \\
\text { for delivery of baby? }\end{array}$ & $130(62.4)$ & $39(18.8)$ & $39(18.8)$ \\
\hline
\end{tabular}




\begin{tabular}{|llcc|}
\hline Do you think obesity increases the risk of delivering a big baby? & $56(26.9)$ & $96(46.2)$ & $56(26.9)$ \\
\hline $\begin{array}{l}\text { Do you think obesity increases the risk of birth of baby which } \\
\text { does not show any signs of life? }\end{array}$ & $31(14.9)$ & $64(30.8)$ & $113(54.3)$ \\
\hline $\begin{array}{l}\text { Is obesity associated with increased bleeding immediately after } \\
\text { delivery? }\end{array}$ & $33(15.9)$ & $64(30.8)$ & $111(53.4)$ \\
\hline $\begin{array}{l}\text { Does obesity increase the risk of infections immediately after } \\
\text { delivery? }\end{array}$ & $36(17.3)$ & $85(40.9)$ & $87(41.8)$ \\
\hline Do you think obesity increases the cost of antenatal care? & $52(25)$ & $99(47.6)$ & $57(27.4)$ \\
\hline $\begin{array}{l}\text { Do you think obese women have higher chances of developing } \\
\text { cancers of genital tract? }\end{array}$ & $24(11.5)$ & $70(33.7)$ & $114(54.8)$ \\
\hline $\begin{array}{l}\text { Do you think obesity is one of risk factors for polycystic ovarian } \\
\text { disease? }\end{array}$ & $66(31.7)$ & $60(28.8)$ & $82(39.4)$ \\
\hline $\begin{array}{l}\text { Do you feel that more awareness programs should be conducted } \\
\text { to provide more information regarding effect of obesity in } \\
\text { reproductive life? }\end{array}$ & $202(97.1)$ & $1(0.5)$ & $5(2.4)$ \\
\hline
\end{tabular}

Majority of women [158(76\%)] had average awareness regarding adverse effects of obesity on their reproductive health. 21(10.1\%) had good awareness while 29(13.9\%) had poor awareness. Generally awareness about maternal complications as a consequence of obesity was more than neonatal complications among participants. Regarding consequences of obesity on obstetric health, $34(16.3 \%)$ of them had poor, $165(79.4 \%)$ had average and $9(4.3 \%)$ had good awareness. Also 46 (22.1\%) participants had poor, $43(20.7 \%)$ had average and $119(57.2 \%)$ had good awareness regarding consequences of obesity on gynaecological health.

Source of information regarding consequences of obesity on reproductive health among study participants were mass media [116(55.8\%)], schooling [68(32.7\%)], doctors [62(29.8\%)], family members [42(20.2\%)], friends [36(17.3\%)], health care workers [10(4.8\%)], Anganwadi workers (employees under integrated child development services of Government of India) [5(2.4\%)], text books and from own experience in two cases each.

Awareness of consequences of obesity on reproductive health was significantly more among participants aged $\leq$ 25 years $(\mathrm{p}=0.03)$, with higher level of education $(\mathrm{p}=0.038)$ and the nulligravid $(\mathrm{p}=0.037)$ (Table 2). The correlation between age and awareness scores showed a significantly negative correlation $(\mathrm{r}=-0.145, \mathrm{p}=0.037)$.

Awareness level was significantly more among the professionals $(\mathrm{p}=0.02) \quad$ (Table 3$)$. There was no association of marital status $(\mathrm{p}=0.2)$ with awareness among participants.

Educational status was significantly higher among participants in the reproductive age group (18 to 45 years) $(\mathrm{p}<0.001)$ and those who had 2 pregnancies or less as well as no pregnancy $(\mathrm{p}=0.009)$ (Table 4$)$.
Table 2: Association between awareness and sociodemographic variables of study participants like age, educational status and number of previous pregnancies $(n=208)$.

\begin{tabular}{|c|c|c|c|}
\hline $\begin{array}{l}\text { Socio- } \\
\text { demographic } \\
\text { variable }\end{array}$ & $\begin{array}{l}\text { Number of } \\
\text { study } \\
\text { participants }\end{array}$ & $\begin{array}{l}\text { Mean } \\
\text { score }\end{array}$ & $\begin{array}{l}\text { Standard } \\
\text { deviation }\end{array}$ \\
\hline \multicolumn{4}{|l|}{ Age } \\
\hline $18-25$ & 38 & 11.34 & 4.47 \\
\hline $26-35$ & 34 & 8.14 & 3.97 \\
\hline $36-45$ & 54 & 9.51 & 4.16 \\
\hline $46-55$ & 51 & 9.13 & 4.78 \\
\hline $56-65$ & 22 & 9.90 & 4.80 \\
\hline \multirow[t]{2}{*}{$>65$} & 9 & 7.22 & 4.14 \\
\hline & & & $\begin{array}{l}F=2.537, \\
p=0.03\end{array}$ \\
\hline \multicolumn{4}{|l|}{$\begin{array}{l}\text { Educational } \\
\text { status }\end{array}$} \\
\hline $\begin{array}{l}\text { Upto } 10^{\text {th }} \\
\text { standard }\end{array}$ & 21 & 7.09 & 2.96 \\
\hline PUC & 49 & 10.12 & 4.41 \\
\hline Undergraduate & 109 & 9.37 & 4.64 \\
\hline \multirow[t]{2}{*}{ Postgraduate } & 29 & 10.48 & 4.60 \\
\hline & & & $\begin{array}{l}\mathrm{F}=2.868 \\
\mathrm{p}=0.038\end{array}$ \\
\hline \multicolumn{4}{|l|}{$\begin{array}{l}\text { Number of } \\
\text { previous } \\
\text { pregnancies }\end{array}$} \\
\hline 0 & 56 & 7.59 & 3.50 \\
\hline 1 & 48 & 6.35 & 2.76 \\
\hline 2 & 78 & 6.59 & 3.42 \\
\hline \multirow[t]{2}{*}{$\geq 3$} & 26 & 5.38 & 3.57 \\
\hline & & & $\begin{array}{l}F=2.882 \\
p=0.037\end{array}$ \\
\hline Total & 208 & 9.48 & 4.5 \\
\hline
\end{tabular}


Table 3: Association between occupations of participants with awareness about health hazards of obesity in reproductive life among participants.

\begin{tabular}{|lllll|}
\hline Socio-demographic variable & Poor knowledge & $\begin{array}{l}\text { Average } \\
\text { knowledge }\end{array}$ & Good knowledge & Total \\
\hline Occupation & & & \\
\hline Doctor, dentist, nurse & $1(10.0 \%)$ & $5(50.0 \%)$ & $4(40.0 \%)$ & 10 \\
\hline Housewives & $13(16.2 \%)$ & $63(78.8 \%)$ & $4(5.0 \%)$ & 80 \\
\hline Teachers & $4(10.3 \%)$ & $33(84.6 \%)$ & $2(5.1 \%)$ & 39 \\
\hline Students & $3(9.4 \%)$ & $23(71.9 \%)$ & $6(18.8 \%)$ & 32 \\
\hline $\begin{array}{l}\text { Businesswomen, self-employed } \\
\text { clerks, anganwadi workers }\end{array}$ & $8(17.0 \%)$ & $34(72.3 \%)$ & $5(10.6 \%)$ & 47 \\
\hline & & & $\mathrm{X}^{2}=17.36, \mathrm{p}=0.02$ \\
\hline
\end{tabular}

Table 4: Association of age and number of previous pregnancies with educational status of study participants $(\mathbf{n}=\mathbf{2 0 8})$.

\begin{tabular}{|llll|}
\hline \multicolumn{2}{l}{ Characteristics } & \multicolumn{2}{l|}{ Total } \\
\hline & $10^{\text {th }}$ standard or less & PUC and above \\
\hline $18-25$ & $0(0)$ & $38(100)$ & 38 \\
\hline $26-35$ & $1(2.9)$ & $33(97.1)$ & 34 \\
\hline $36-45$ & $4(7.4)$ & $50(92.6)$ & 54 \\
\hline $46-55$ & $7(13.7)$ & $44(86.3)$ & 51 \\
\hline $56-65$ & $4(18.2)$ & $18(81.8)$ & 22 \\
\hline$>65$ & $5(55.6)$ & $4(44.4)$ & 9 \\
\hline & & $X^{2}=29.431, \mathrm{p}<0.001$ \\
\hline $\begin{array}{l}\text { No. of previous } \\
\text { pregnancies }\end{array}$ & & & \\
\hline Zero & $0(0)$ & $56(100)$ & 56 \\
\hline One & $6(12.5)$ & $42(87.5)$ & 48 \\
\hline Two & $9(11.5)$ & $69(88.5)$ & 75 \\
\hline Three or more & $6(23.1)$ & $20(76.9)$ & 26 \\
\hline & & 187 & $\mathrm{X}^{2}=11.6, \mathrm{p}=0.009$ \\
\hline Total & 21 & 208 \\
\hline
\end{tabular}

\section{DISCUSSION}

Improving women's awareness on the short and long term risks of obesity to both self and their offspring's health is likely to be an important initial step in preventing obesity in pregnancy. ${ }^{23}$

This study found that about $80 \%$ women knew that excess weight adversely affects reproductive health outcomes which was more than that reported by $75 \%$ participants in a study done in Brisbane, Australia ${ }^{23}$ and $49 \%$ in Chicago, USA based study. ${ }^{24}$ However the level of awareness in the present study was good only in about $10 \%$ participants in comparison to $49.8 \%$ reported in a study done in Nigeria while poor awareness in this study was seen in about $14 \%$ participants in comparison to $39.5 \%$ reported in the Nigerian study. ${ }^{25}$

As women of reproductive age will be responsive to education on consequences of obesity on reproductive health, elaborate information needs to be widely disseminated in the community to bring about behavioral modifications. ${ }^{15}$

Awareness of increased risk of caesarean deliveries was stated by $30.8 \%^{15}$ and $60 \%{ }^{23}$, stillbirths by $14.1 \%{ }^{15}$, menstrual irregularities by $35.8 \%{ }^{15}$ and infertility by $33.9 \%^{15}$ in previous studies which were less than those 
reported by participants in this study. However figures of risk of gestational diabetes reported by $86.5 \%{ }^{23}, \mathrm{PIH}$ by $88.2 \%{ }^{23}$, pre-term delivery by $60.9 \%^{23}$, miscarriage by $37.5 \%{ }^{15}$ and uterine cancer by $18.1 \%^{15}$ and $42 \%^{26}$ of participants in other studies were more than our observations.

The awareness of congenital anomalies among offspring was $23.7 \%$ in a study done in Chicago ${ }^{15}$ and $58 \%$ in a study done in Brisbane ${ }^{23}$ in comparison to $26.4 \%$ reported by participants in this study. Another Australian study observed that awareness of the role of obesity in maternal complications was much more for maternal than neonatal complications which was similar to our findings. ${ }^{23}$ One of the ultimate aims of antenatal care is birth of a healthy baby and therefore information on neonatal complications like birth defects might encourage women to prevent obesity prior to pregnancy. ${ }^{23,27}$

Source of information of more than half of participants in this study was mass media sources like television. In a Nigerian study the source was mostly from the internet among $47.3 \%$ participants. ${ }^{25}$ A Texas, USA based study also found that internet use was associated with higher knowledge scores among participants. ${ }^{28}$ Therefore, attempts to improve obesity-related awareness on reproductive health can utilize mass media sources which are widely accessed by people worldwide. Also almost all participants in this study $(97.1 \%)$ want to know about reproductive health problems which is a positive sign for health educators.

In this study the awareness scores were significantly higher among participants of younger age group which was also observed in another study done in Coimbatore, India. ${ }^{16}$ But a study done in Nigeria $^{25}$ found no association with age while a study done in Texas ${ }^{28}$ found that awareness scores improved with age of the participants. This was different from our findings probably because educational status was significantly higher among younger participants in this study.

Educational status significantly influencing awareness among participants as observed in this study was also supported by findings of several other studies. ${ }^{15,16,21,23,28}$ This supports the fact that female literacy is the main determinant to be considered before designing education campaigns. $^{23}$ Only the study done in Nigeria found no association of level of educational status of participants with awareness of obesity as a risk factor in adverse reproductive health outcomes..$^{25}$

In this study awareness about consequences of obesity was related significantly with occupation as also observed in other studies. ${ }^{21,16}$ Association of marital status with knowledge was significant in a study done in Chicago, USA which differed from our findings. ${ }^{24}$ An interesting observation made in this study was that awareness level was found to significantly decrease with increasing gravida contrary to the expectation that it would improve following each experience of child bearing. This could probably be due to better educational status among young participants who were mainly nulligravid. This could also indicate lack of educational interventions by medical personnel regarding adverse consequences of obesity even after repeated pregnancies. Callaway et al, ${ }^{29}$ observed that only $23 \%$ of overweight women and $36 \%$ of obese women prior to conceiving were advised to lose weight by their doctors. This highlights the importance of educating obese patients about consequences of obesity on reproductive problems as well as counseling them to adopt behavioral change for its prevention during adolescent period and in ante natal care visits which can be best done by obstetricians only. Louis et al, ${ }^{30}$ observed that women are more motivated to engage in healthy behaviors during pregnancy and hence is an ideal period to plan such interventions.

\section{CONCLUSIONS}

Even though all participants in this study were literate and $80 \%$ of them were aware of consequences of obesity on reproductive health only $10 \%$ had good level of awareness. Mass media was reported to be the commonest source of information amongst majority of participants. Hence these sources need to be widely used to disseminate information regarding risks of conceiving when obese. Need for pre pregnancy health check-up with appropriate educational interventions should also be emphasized so that body mass index can be checked and preconception counselling and timely health education can be provided. This would probably bring about the required behavioural change about obesity prevention among women resulting in further improvement in reproductive health in this setting.

\section{Strengths of this study}

The random selection of participants in the settings makes the findings of this study generalizable to this setting and to other urban areas of developing countries. The study identified specific aspects on reproductive health where awareness was lacking. Also awareness of neonatal complications was found to be poorer compared to maternal complications. Very few studies have been done worldwide to assess the awareness of consequences of obesity on reproductive health problems among women. Identifications of socio demographic groups in whom awareness was particularly poor is also another important observation. These groups need to be focused upon during future awareness campaigns in this setting.

\section{Limitations}

This study assessed the awareness dimension regarding reproductive health problems among women in an urban setting only. Rural areas were not surveyed in this study. Moreover assessment of body mass index of participants followed by active interventions for correction of obesity among participants could not be done due to time constraints. However as there are dearth in studies on this 
issue in India we recommend more of such studies to be done in future.

Funding: Indian Council of Medical Research Conflict of interest: None declared

Ethical approval: Kasturba Medical College Institutional Ethics Committee

\section{REFERENCES}

1. IIPS (International Institute for Population Sciences), Macro International National Family Health Survey (NFHS-3), 2005-06, 2007; India,Vol. 1, Mumbai: IIPS; 2007.

2. Gesink Law DC, Maclehose RF, Longnecker MP. Obesity and time to pregnancy. Hum Reprod. 2007;22:414-20.

3. Ramlau-Hansen $\mathrm{CH}$, Thulstrup AM, Nohr EA, Bonde JP, Sørensen TI, Olsen J. Subfecundity in overweight and obese couples. Hum Reprod. 2007;22:1634-7.

4. Metwally M, Ong KJ, Ledger WL, Li TC. Does high body mass index increase the risk of miscarriage after spontaneous and assisted conception? A metaanalysis of the evidence. Fertil Steril. 2008;90:71426.

5. Lashen H, Fear K, Sturdee DW. Obesity is associated with increased risk of first trimester and recurrent miscarriage: matched case-control study. Hum Reprod. 2004;19:1644-6.

6. Thornburg LL. Antepartum obstetrical complications associated with obesity. Semin Perinatol. 2011;35:317-23.

7. O'Brien TE, Ray JG, Chan WS. Maternal body mass index and the risk of preeclampsia: a systematic overview. Epidemiology. 2003;14:368-74.

8. Dokras A, Baredziak L, Blaine J, Syrop C, VanVoorhis BJ, Sparks A. Obstetric outcomes after in vitro fertilization in obese and morbidly obese women. Obstet Gynecol. 2006;108:61-9.

9. Solomon CG, Willett WC, Carey VJ, Rich-Edwards J, Hunter DJ, Colditz GA et al. A prospective study of pregravid determinants of gestational diabetes mellitus. JAMA. 1997;278:1078-83.

10. Rosenberg TJ, Garbers S, ChavkinW, ChiassonMA. Prepregnancy weight and adverse perinatal outcomes in an ethnically diverse population. Obstet Gynecol. 2003;102:1022-7.

11. Vahratian A, Siega-Riz AM, Zhang J, Troendle J, Savitz D. Maternal pre-pregnancy overweight and obesity and the risk of primary cesarean delivery in nulliparous women. Ann Epidemiol. 2005;15:46774.

12. Vahratian A, Zhang J, Troendle J, Savitz D, SiegaRiz AM. Maternal pre-pregnancy overweight and obesity and the pattern of labor progression in term nulliparous women. Obstet Gynecol. 2004;104:94351 .
13. Bodnar LM, Siega-Riz AM, Cogswell M. High pregnancy body mass index increases the risk of postpartum anemia. Obes Res. 2004;12:941-8.

14. Ramsay JE, Greer I, Sattar N. ABC of obesity Obesity and reproduction. BMJ 2006;333:1159-62.

15. Cardozo ER, Dune TJ, Neff LM, Brocks ME, Ekpo GE, Barnes RB et al. Knowledge of obesity and its impact on reproductive health outcomes among urban women. J Community Health. 2013;38:261-7.

16. Sekar V, Mathew AC, Chacko TV. Awareness of women about complications and causes of obesity. A cross sectional study in Coimbatore, South India. South Asian Journal of Preventive Cardiology. Available from: http://sajprevcardiology.com/vol8/vol8_3/awareness ofwomen.htm

17. Stothard KJ, Tennant PW, Bell R, Rankin J. Maternal overweight and obesity and the risk of congenital anomalies: a systematic review and metaanalysis. JAMA 2009;301:636-50.

18. Anderson JL, Waller DK, Canfield MA, Shaw GM, Watkins ML, Werler MM. Maternal obesity, gestational diabetes, and central nervous system birth defects. Epidemiology. 2005;16:87-92.

19. Eliassen AH, Colditz GA, Rosner B, Willett WC, Hankinson SE. Adult weight change and risk of postmenopausal breast cancer. JAMA. 2006;296:193-201.

20. Modesitt SC, van Nagell JR Jr. The impact of obesity on the incidence and treatment of gynecologic cancers: a review. Obstet Gynecol Surv. 2005;60:683-92.

21. Ojofeitimi EO, Adeyeye AO, Fadiora AO, Kuteyi AO, Faborode TG, Adegbenro CA et al. Awareness of obesity and its health hazard among women in a university community. Pakistan Journal of Nutrition. 2007;6:502-5.

22. World Health Organisation (WHO) Global Strategy of Diet, Physical Activity and Health (Obesity and Overweight) London; 2003. Available from: http://www.who.int/hpr/NPH/docs/gs_obesity.pdf [Last accessed on 2012 Oct 22].

23. Nitert MD, Foxcroft KF, Lust K, Fagermo N, Lawlor DA, O'Callaghan $\mathrm{M}$ et al. Overweight and obesity knowledge prior to pregnancy: a survey study. BMC Pregnancy Childbirth. 2011;11:96.

24. Kominiarek MA, Vonderheid S, Endres LK. Maternal obesity: do patients understand the risks? Journal of Perinatology. 2010;30:452-8.

25. Awotidebe TO, Adedoyin RA, Fatoogun B, Adeyeye V, Mbada CE, Akinola OT et al. An assessment of knowledge of Nigerian female undergraduates on obesity as a risk factor for cardiovascular disease in women. American Journal of Health Research. 2014;2:50-5.

26. Soliman PT, Bassett RL, Jr, Wilson EB, BoydRogers S, Schmeler KM, Milam MR et al. Limited public knowledge of obesity and endometrial cancer risk: what women know. Obstet Gynecol. 2008;112:835-42. 
27. Luo ZC, Wilkins R, Kramer MS. Effect of neighbourhood income and maternal education on birth outcomes: a population-based study. CMAJ. 2006,174:1415-20.

28. Rahman M, Justiss AA, Berenson AB. Racial differences in obesity risk knowledge among lowincome reproductive-age women. J Am Coll Nutr. 2012;31:397-400.

29. Callaway LK, O’Callaghan MJ, McIntyre HD. Barriers to addressing overweight and obesity before conception. The Medical journal of Australia. 2009;191:425-8.

30. Louis GM, Cooney MA, Lynch CD, Handal A. Periconception window: advising the pregnancyplanning couple. Fertil Steril. 2008;89(2):e119-21.

Cite this article as: Joseph N, Sneha V, Nelliyanil M, Rai S, Supriya K, Bhat K. Awareness of consequences of obesity on reproductive health problems among women in an urban area in South India. Int J Reprod Contracept Obstet Gynecol 2015;4:1109-16. 